\title{
A POSSIBILIDADE DE CONCESSÃO DE DANO EXTRAPATRIMONIAL EM FAVOR DO NASCITURO NA PERSPECTIVA DO DIREITO CIVIL E CONSTITUCIONAL
}

\author{
THE POSSIBILITY OF GRANTING OFF-BALANCE SHEET IN FAVOUR OF THE \\ UNBORN CHILD FROM THE PERSPECTIVE OF CIVIL AND CONSTITUTIONAL LAW
}

Cátia Rejane Liczbinski Sarreta

\begin{abstract}
Doutora em Ciências Sociais pela UNISINOS. Graduação em Direito pela UNIJUI, especialização em Direito Privado e Mestrado em Desenvolvimento, Gestão e Cidadania pela Universidade Regional do Noroeste do Estado do Rio Grande do Sul. Professora da UNIVEL no curso de Direito. Professora em cursos de Pós-Graduação, como da FGV. Coordenadora de Grupos de Pesquisa. Pesquisadora. Atua principalmente nos seguintes temas: Hermenêutica, Meio Ambiente, Consumidor, Direitos Fundamentais, Direitos

Humanos, Desenvolvimento, Processo Civil, Ética, Sociologia Jurídica e Direito Constitucional. E-mail: catia_sarreta@hotmail.com
\end{abstract}

Mariana Mrosk Teixeira Acadêmica de Direito da UNIVEL. E-mail: mahrianah@hotmail.com

Recebido em: 25/07/2016

Aprovado em: 17/10/2016

Doi: $10.5585 / \mathrm{rdb} . v 15 i 6.447$

\begin{abstract}
RESUMO: Este trabalho pretende analisar a proteção dos direitos do nascituro, especialmente em relação ao dano extrapatrimonial que este possa vir a sofrer, estudando sua perspectiva no Direito Civil e Direito Constitucional Brasileiro. Com o objetivo de demonstrar que o nascituro é merecedor de direitos desde a concepção, serão analisadas as quatro teorias a respeito do início da personalidade civil, fazendo um comparativo com os ditames da Constituição Federal, ponderando o princípio da dignidade humana como principal fundamento para a efetivação dos direitos do nascituro. Buscando uma aplicação prática, diversas doutrinas, legislações e jurisprudências serão estudadas minuciosamente, chegando a principal conclusão de que, a responsabilização civil configurada em reparação de danos extrapatrimoniais ao nascituro é uma das formas de materialização de sua tutela, protegendo todo ser humano em qualquer estado de desenvolvimento em que se encontra. Para isso, utiliza-se do método dedutivo geral para os casos concretos em estudo.
\end{abstract}

Palavras-Chave: Nascituro. Dano extrapatrimonial. Direito Civil. Constituição Federal. Personalidade jurídica.

ABSTRACT: This study intends to analyze the protection of the unborn child rights, specially in relation to the off-balance sheet that it may suffer, studying their perspective on Brazilian Civil and Constitutional Law. With the aim to demonstrate that the unborn child deserves their rights from the moment of conception, four theories about the beginning of the legal personality will be examined, making a comparative with the dictates of the Federal Constitution, considering the principle of human dignity as the main foundation for the achievement of the rights of the unborn 
child. Seeking a practical application, several doctrines, legislation and case law will be studied thoroughly, reaching the principal conclusion that the civil liability set to repair off-balance sheet to the unborn child, is one of the ways to materialize his tutelage, protecting every human being in any level of development they are. Using the general deductive method for the cases in study.

Keywords: Unborn child. Off-balance sheet. Civil Law. Federal Constitution. Legal personality.

SUMÁRIO: Introdução; 1. Conceito de nascituro; 1.1 Teoria natalista; 1.2 Teoria da personalidade condicional; 1.3 Teoria concepcionista; 1.4 Teoria pré-concepcionista; 2. Direitos Civis do nascituro no Sistema Jurídico Brasileiro; 2.1 Direitos do nascituro frente aos outros ramos do direito; 2.2 Adoção da Teoria da Personalidade condicional no Código Civil; $2.3 \mathrm{O}$ nascituro e a Constituição Federal Brasileira de 1988; 2.4 O conflito aparente entre a Constituição Federal Brasileira e o Código Civil Brasileiro; 3. A confusão entre Dano Moral e Dano Extrapatrimonial na Jurisprudência e Doutrina Brasileira; 3.1 Dano Moral; 3.2 Dano Extrapatrimonial; 3.3 Distinção entre Dano Extrapatrimonial e Dano Moral; 4. Aplicação do Dano Extrapatrimonial em face do nascituro; 4.1 Justificativa legal e doutrinária da aplicação do Dano Extrapatrimonial em favor do nascituro; 4.2 Entendimentos Jurisprudenciais; 4.3 Breve explanação sobre o Projeto do estatuto do nascituro; Considerações finais; Referências.

\section{INTRODUÇÃO}

O assunto abordado neste artigo, se dará no âmbito dos direitos do nascituro, especialmente, o seu direito a danos extrapatrimoniais. No ordenamento jurídico brasileiro, essa reparação imaterial teve sua aparição, de forma mais concreta, na Constituição Federal de 1988, com o artigo $5^{\circ}$, inciso $\mathrm{X}$, que assegura o direito a indenização pelo dano material ou moral sofrido por alguém, em decorrência da violação de algum direito.

O dever de indenizar, significa reparar algum dano causado à vítima, na sua totalidade, restaurando sempre que possível o "statu quo ante", ou seja, voltando ao estado em que se encontrava antes da ocorrência do ato ilícito. Como regra, a obrigação de indenizar limita-se ao dano patrimonial, porém, tal sentido pode ser estendido no caso de alguma desvantagem aos bens jurídicos, tais como, corpo, dignidade, vida, saúde, honra, bem-estar e etc., nascendo nesses casos, o dever de indenizar pelo dano extrapatrimonial sofrido.

Aliado a isso, há que se falar na figura do nascituro, objeto desse trabalho, que possui direitos e obrigações, ou expectativas deles, que devem ser observados de forma especial, interpretando o conjunto de leis existentes para tanto. Nascituro é aquele que há de nascer, já concebido porém ainda não "parido" com vida. Novamente, em interpretação ao Código Civil, percebe-se que o artigo $2^{\circ}$, aduz que a personalidade civil da pessoa começa do nascimento com vida, porém, colocando a salvo os direitos do nascituro desde a concepção.

Assim, a grande questão encontra-se no âmbito dos direitos daquele que, ainda não nascido, deva ser protegido em seu todo, especialmente em relação a reparação civil de possível dano sofrido por ele. Nesse sentido, o problema a ser abrangido por esta pesquisa encontra-se na seguinte indagação: Diante da Constituição Federal Brasileira de 1988 e do Código Civil Brasileiro, é possível a indenização por danos extrapatrimoniais em favor do nascituro?

É possível encontrar diversas interpretações relacionadas à essa questão, especialmente quando se trata de dano moral e dano extrapatrimonial. O tema nascituro para o direito, dá origem a várias indagações jurídicas, sobre sua personalidade, sobre ser ou não sujeito de direitos e, em particular desse trabalho, sobre a possível indenização de dano extrapatrimonial à ele, no que respeita ao artigo $2^{\circ}$ do Código Civil e os artigos $1^{\circ}$, inciso III; $3^{\circ}$, inciso IV e $5^{\circ}$ "caput", da Constituição Federal. 
$\mathrm{O}$ assunto analisado nesse trabalho trata-se de uma questão atual, isso porque com a evolução jurídica dos direitos civis e com o crescimento das relações entre as pessoas, surgem diversas situações controversas que devem ser analisadas com cautela, como é o caso da aplicação de dano extrapatrimonial ao nascituro.

Modernamente, a preocupação em garantir os direitos à qualquer ser humano, tenha ele personalidade jurídica ou não, vai além do direito à vida, atingindo também, a dignidade humana, a liberdade, a convivência familiar, entre outros, devendo ser reparados aqueles danos sofridos por qualquer ser vivo.

Destarte, não restam dúvidas que o assunto em debate desperta muito interesse, afinal, já está sendo amplamente discutido dentro do judiciário, uma vez que existem várias decisões favoráveis à concessão de dano extrapatrimonial ao nascituro atingido.

Serão abordados nesse trabalho, diversas questões sobre seus direitos, falando principalmente das 4 teorias civilistas existentes, que dispõe sobre o início da personalidade civil do nascituro. São elas: Teoria Natalista, Teoria da Personalidade Condicional, Teoria Concepcionista e Teoria Pré-Concepcionista (teoria moderna).

Além disso, nos próximos parágrafos serão abordados alguns pontos de vista de pesquisadores do direito, assim como, entendimentos jurisprudenciais sobre a possibilidade de concessão do dano extrapatrimonial em favor do nascituro, destacando os aspectos cruciais para a solução da controvérsia.

Demonstrando por fim, a necessidade de proteção integral ao nascituro, uma vez que trata-se de sujeito frágil e indefeso, colacionando os entendimentos favoráveis à tal premissa, utilizando-se do método dedutivo geral para os casos concretos em estudo.

\section{CONCEITO DE NASCITURO}

A palavra nascituro tem origem latina, do termo "nasciturus", que refere-se à aquele que foi concebido, porém que ainda não nasceu. As fontes jurídicas romanas, citam diversos termos e expressões que tentam denominar o que se tem hoje por nascituro, como por exemplo: partus, qui est in ventre, qui in útero est, conceptus, entre outros (MADEIRA, 2005).

No direito pátrio, a utilização do termo nascituro, em si, restringe o seu sentido a fim de excluir aqueles ainda não concebidos, isto é, a prole eventual. Percebe-se, que tal ideia não é unânime em outros países, uma vez que:

Na doutrina moderna de outros países de língua latina, o termo nascituro não adquiriu unanimemente a restrição que entre nós se assentou, sendo comum, em Portugal, Itália e França, o emprego das expressões "nascituro concebido" e "nascituro não concebido" ou equivalentes, contrárias portanto àquela originaria no direito comum (MADEIRA, 2005, p. 12).

Formulados em termos diversos, o nascituro aparece em muitos estudos que visam atribuir um conceito minimamente correto a fim de se estabelecer direitos e, acima de tudo, compreensão quanto ao momento do início da vida.

Ressalta-se que está cada vez mais em ascensão a idéia do reconhecimento do embrião como um ser vivo, desde a concepção, merecedor de tutela jurídica durante todo o período da gestação. Apesar disso, a existência de um ser vivo autônomo, isto é, distinto dos pais e dotado de vida em um processo de desenvolvimento, certamente culminará no nascimento de uma pessoa. Porém, a individualidade da pessoa do nascituro não obsta a compreensão de sua dependência direta daqueles que o geraram (PAGANINI, 2008).

Maria Helena Diniz aduz que o termo nascituro refere-se à: 
Aquele que há de nascer, cujos direitos a lei põe a salvo. Aquele que, estando concebido, ainda não nasceu e que, na vida intra-uterina, tem personalidade jurídica formal, no que atina aos direitos de personalidade, passando a ter personalidade jurídica material, alcançando os direitos patrimoniais, que permaneciam em estado potencial, somente com o nascimento com vida (2008, p. 334).

Há um ponto importante a se destacar, que se dá no que tange à concepção no ventre materno, entendida como sinônimo de gravidez ou gestação, ou no que diz respeito às concepções extra-uterinas (fecundação in vitro). Para essa discussão a estudiosa do direito Chinelato e Almeida aponta que:

É óbvio que durante esse período de desenvolvimento extra-corpóreo do ovo, a mulher não pode ser considerada grávida; tampouco o ovo terá condições de se desenvolver caso não seja transferido para o útero da futura mãe [...] não se poderá falar em "nascituro" quanto o ovo (óvulo fertilizado in vitro) não tiver sido implantado na futura mãe impondo-se, pois, o conceito de nascituro sempre e apenas quando haja gravidez, seja ela resultado de fecundação in anima nobile (obtida naturalmente ou por inseminação artificial), seja de fecundação in vitro (2000, p. 9).

Em sentido contrário, Willian Arthur Pussi (2005) conclui que a maioria dos autores brasileiros atribui o caráter de pessoa aos concebidos in útero e in vitro, não restringindo o conceito de nascituro apenas àquele que se encontra em gestação.

Tais conceitos e entendimentos serão vistos adiante, nas teorias que buscam precisar o início da personalidade e que explicam, cada qual, o momento em que o nascituro é considerado possuidor de direitos. Destacam-se, nesse sentido, quatro principais teorias, quais sejam: Teoria Natalista, Teoria da Personalidade Condicional, Teoria Concepcionista e Teoria PréConcepcionista.

\subsection{Teoria Natalista}

Segundo a Teoria Natalista, o nascituro não é uma vida a parte de sua genitora (individualizado), sendo apenas parte do ventre materno, entendendo que o termo inicial da personalidade jurídica é o nascimento com vida, isto é, devendo nascer com vida para o início de sua personalidade. Ela permeia a maioria dos códigos do mundo, dentre ele os da França, Espanha, Portugal, Chile, Alemanha, Suíça, Itália e Japão (BEVILAQUA, 1959).

Para essa teoria, como a personalidade advém do nascimento, não seria o nascituro pessoa: a personalidade subordina-se à condição suspensiva de nascer com vida. Se ela verificar-se, há efetiva aquisição de direitos, se não, não haverá perda ou transmissão dos mesmos porque a personalidade não existiu (ROESSING, 2001, p. 52).

Dessa forma, o útero seria essencial para a formação do novo ser, uma vez que, nessa concepção, admite-se o início da personalidade, tão somente a partir do nascimento com vida.

\subsection{Teoria da Personalidade Condicional}

De acordo com o Código Civil Brasileiro de 2002, em seu artigo $2^{\circ}$, a personalidade civil começa do nascimento com vida, colocando a salvo os direitos do nascituro desde a 
concepção. Dessa forma, verifica-se que o direito positivo adotou a teoria em questão, uma vez que se exige o nascimento com vida para ter início a personalidade, porém, antes mesmo do início da personalidade, o nascituro já tem seus direitos resguardados.

Meirelles (2000), faz uma distinção importante entre a doutrina da personalidade condicional e a doutrina concepcionista, a qual será visto no tópico a seguir. Para ela, a primeira doutrina, ensina que a personalidade civil tem início com a concepção, sob a condição resolutiva de nascer com vida. Já a segunda estabelece o mesmo marco para a atribuição da personalidade, porém, desde a concepção, o nascituro seria considerado pessoa.

Coaduna Maria Helena Diniz que:

O nascituro tem capacidade de direito, mas não de exercício, devendo seus pais ou, na incapacidade ou impossibilidade deles, o curador ao ventre ou ao nascituro zelar pelos seus interesses, tomando medidas processuais ao seu favor, administrando em seu nome a posse, resguardando sua parte na herança, aceitando doações ou pondo a salvo suas expectativas de direito. Com o nascimento com vida, seus pais assumem o poder familiar; se havia curador ao ventre, cessar-se-ão suas funções, terminando a curatela, nomeando-se um tutor ao nascido (2008, p. 229-230).

A teoria da personalidade condicional apresenta-se como uma subdivisão da ótica concepcionista, oferecendo uma visão onde reconhece a personalidade desde a concepção, porém condicionada ao nascimento com vida. Os adeptos à essa teoria concordam que a lei assegura direitos ao nascituro durante o período da gestação, tutelando-lhes alguns direitos personalíssimos e patrimoniais, porém, estariam eles sujeitos a uma condição resolutiva, qual seja, do nascimento com vida.

Miguel Maria de Serpa Lopes, citado na obra de Willian Artur Pussi, leciona que:

De fato, a aquisição de tais direitos, segundo o nosso Código Civil, fica subordinado a condição de que o feto venha a ter existência; se tal se sucede, dáse a aquisição; mas ao contrário, se não houver o nascimento com vida, ou por ter ocorrido um aborto ou por ter o feto nascido morto, não há uma perda ou transmissão de direitos, como deverá se suceder; se ao nascituro fosse reconhecida uma ficta personalidade. Em casos tais, não se dá a aquisição de direito (2005, p. 94).

Essa condição suspensiva vem como forma a consolidar os direitos que o nascituro adquirira desde a concepção, tendo em vista que sua eficácia estava atrelada a condição do nascimento com vida, e desta forma integrarão definitivamente o patrimônio do nascituro, mesmo que venha a falecer segundos após ter vindo ao mundo.

\subsection{Teoria Concepcionista}

Já para a Teoria Concepcionista, tem-se a personalidade do homem desde o momento da concepção, argumentando que tendo o nascituro alguns direitos, deve ser considerado pessoa e, consequentemente, sujeito de direitos.

Juridicamente entram em perplexidade total aqueles que tendem afirmar a impossibilidade de atribuir capacidade ao nascituro 'por este não ser pessoa'. A legislação de todos os povos civilizados é a primeira a desmenti-lo. Não há nação que se preze (até a China) onde não se reconheça a necessidade de proteger os direitos do nascituro (Código chinês, art. $1^{\circ}$ ). Ora, quem diz direitos, 
afirma capacidade. Quem afirma capacidade, reconhece personalidade. (CHINELATO, 2000, p. 159-160).

Ademais, para ela, a codificação estabelece direitos ao nascituro, e por correspondência à lógica do sistema, este deve ser pessoa, pois só ela pode deter titularidade (CHINELATO, 2000).

De acordo com essa teoria, a personalidade começa antes do nascimento, isso porque desde a concepção já há a proteção dos interesses do nascituro, que devem ser assegurados prontamente, uma vez que o mesmo é sujeito de direitos.

A ideia de individualização no mundo real baseia-se em dois pressupostos: a distinção e autonomia, que significam, respectivamente, ser destacado do todo, reconhecível, e manter organizada, em unidade a pluralidade de elementos que lhe compõe. A despeito do transcurso do tempo. Verifica-se que a compreensão da individualidade dos seres vivos é bastante complexa, pois advém de um processo de individuação. Há dificuldades na identificação do começo do ser vivo, gerado por reprodução sexuada, em razão da forma organicamente sequenciada da geração de vida. No que diz respeito à espécie humana, essa forma de reprodução, em que as etapas se sobrepõem e se concatenam, permite que alguns entendam que o embrião não passa ovo (SIC). De toda forma, o ser humano possui uma singularidade muito antes do seu nascimento (ESPOLADOR, 2010, p. 14).

Assim, é assegurada proteção ampla dos direitos do nascituro e, não apenas, uma mera expectativa deles. Nesse sentido, observa-se hoje uma crescente necessidade de conferir uma forma mais abrangente da tutela ao nascituro, não ao que concerne somente aos seus direitos patrimoniais, mas de forma a assegurar-lhe outros direitos mais primordiais, como é o caso dos danos extrapatrimoniais.

\subsection{Teoria Pré-Concepcionista}

Essa última teoria em estudo, compreende considerações inovadoras, remetendo-se aos avanços tecnológicos que permeiam as últimas décadas. Dessa forma, muitas questões atinentes à proteção jurídica do embrião in vitro, enfrentam a problemática da conceituação da natureza de tal embrião, o que, com essa teoria em estudo visa protegê-los, sendo essa uma realidade nova e distanciada da estrutura normativa clássica.

Para alguns entendedores do direitos, como Fábio Ulhoa Coelho (2003), essa teoria dispõe que desde o momento da fecundação do óvulo pelo espermatozoide, já estariam preenchidas todas as condições para considerar existente um novo ser.

A teoria pré-concepcionista tende a proteger aqueles embriões humanos concebidos in vitro, que ainda não foram implantados no útero da mulher. Já que, originalmente referia-se à concepção in utero, deixando de lado aqueles concebidos porém, ainda não introduzidos.

Partindo desse princípio: "Nenhuma razão tem para não admitir que, mesmo antes da nidação, não seja o embrião ainda pessoa, pelo único fato de não estar no ventre da mãe, considerando que o embrião é efetivamente um ser concebido" (SEMIÃO, 2000, p. 174).

A respeito dessa teoria e sua classificação no Código Civil:

O pré-embrião poderia ser no máximo prole eventual, se por não pertencer ao ventre materno for considerado não concebido, na medida em que essa condição se mostra essencial ao desenvolvimento futuro do ser. Mas biologicamente a concepção já se observa, com a união de gametas, o que tira o fundamento dessa 
classificação. Não poderiam também ser considerados nascituros, pois não são pessoas a nascer após o decorrer de nove meses, estando com seu desenvolvimento estacionado pela tecnologia. (...) Mesmo que se atribua personalidade jurídica aos embriões mantidos in vitro, considerando-os "pessoa", sua caracterização como sujeito de direito teria que se submeter à condição suspensiva de implante no útero e à condição resolutiva, que poderia ser o nascimento sem vida ou a não implantação. (...) Se visto como um valor, o embrião é considerado para além de sua biologia, como objeto do projeto parental de procriar e portanto, como um ideal da Humanidade (ROESSING, 2001, p. 59).

Assim, verifica-se que para a sua verdadeira efetivação implicaria em uma mudança drástica no ordenamento jurídico brasileiro, assim como, nos preceitos culturais. Além disso, afirma-se novamente a necessidade de proteção da pessoa como um valor e não como uma simples categoria jurídica, uma vez que desde o seu início deve ser imposto a qualquer um, o respeito à dignidade do ser humano.

\section{DIREITOS CIVIS DO NASCITURO NO SISTEMA JURÍDICO BRASILEIRO}

Para chegar ao cerne do problema desse trabalho, analisando se seria possível a concessão de dano extrapatrimonial ao nascituro, é imprescindível, primeiramente, esclarecer a visão dos direitos do nascituro, nos dois principais institutos em análise no presente artigo: o Código Civil Brasileiro e a Constituição Federal Brasileira.

\subsection{Direitos do nascituro frente aos outros ramos do direito}

Antes de adentrar na questão da possível concessão de dano extrapatrimonial ao nascituro, há que se fazer uma relação sobre seus direitos dentro de todo o ordenamento jurídico pátrio.

Quando fala-se em nascituro, não é difícil encontrar, dentro do próprio ordenamento jurídico brasileiro, convicções sobre os direitos que ele possui, desde sua concepção, uma vez que em diversos ramos do direito é possível deparar-se com a proteção do nascituro em toda a sua esfera.

No Direito Penal, por exemplo, o nascituro é protegido em seu todo desde o momento em que há a sua concepção, tanto é verdade, que pune-se a prática de aborto, admitindo tão somente, em alguns casos específicos, no qual há uma ponderação de princípios.

Ainda, quando se fala em proteção àquele não nascido, há que se falar nos alimentos gravídicos. Esse direito é defendido por Pontes de Miranda que aduz:

A obrigação de alimentar também pode começar antes do nascimento e depois da concepção (Código Civil, arts. 397 e $4^{\circ}$ ), pois, antes de nascer, existem despesas que tecnicamente se destinam à proteção do concebido e o direito seria inferior à vida se acaso recuasse atendimento a tais relações interumanas, solidamente fundadas em exigências de pediatra (1974, p. 215).

Portanto, percebe-se pelos sucintos exemplos acima, que há a proteção do nascituro, desde a concepção, em outros ramos do direito brasileiro, o que deve ser visto com tamanha importância a fỉm de servir como comparação, para que seja estudado o ponto principal desse artigo, qual seja, o da possibilidade de dano extrapatrimonial em favor do nascituro na esfera civil, visando sua proteção de forma mais abrangente. 


\subsection{Adoção da Teoria da Personalidade Condicional no Código Civil}

No ordenamento jurídico atual, verifica-se que o nascituro é uma mera expectativa de direitos, ficando essas garantias sob condição suspensiva e concretizados, tão somente, a partir do nascimento com vida.

A Teoria da Personalidade Condicional está pautada no Código Civil em seu artigo $2^{\circ}$, que aduz: "A personalidade civil da pessoa começa do nascimento com vida; mas a lei põe a salvo, desde a concepção, os direitos do nascituro”.

Sobre a ligação de atribuição de personalidade aos seres humanos e a tendência de serem sujeitos de direito, explica pontualmente Gustavo Tepedino:

A noção de personalidade acaba sendo utilizada a um só tempo como valor e como aptidão para ser sujeito de direito. Resultam daí dois equívocos graves. Em primeiro lugar, a atribuição do valor jurídico representado pela personalidade indistintamente a pessoas naturais e jurídicas. Em segundo lugar, a atribuição de personalidade a todos entes a quem o ordenamento confere a qualidade de ser sujeito de direito. Tais conclusões não colhem. Personalidade como valor, há se disse, é característico da pessoa humana, atraindo, por isso mesmo, disciplina jurídica típica e diferenciada, própria das relações jurídicas existenciais (2007, p. 4).

Ressalta-se que para o Direito Civil, o nascituro não é sujeito de direito, embora apresente uma personalidade condicional. $\mathrm{O}$ nascituro segue apenas tendo uma potencialidade de direitos, isto é, como se, iniciando embora a personalidade a partir do nascimento com vida e assentando que os direitos do nascituro retroagem à data da concepção, não seria ilógico afirmar que a personalidade se encontra em estado potencial, somente vindo a concretizar-se com o nascimento (PEREIRA, 2014).

Porém, em que pese o Código Civil apenas garantir direitos ao nascituro e apenas concretizá-los com o nascimento com vida, percebe-se uma crescente adoção da teoria concepcionista pelos tribunais tupiniquins, conforme será demonstrando em momento oportuno, justificando que, o conceito existente no artigo $2^{\circ}$ do Código Civil Brasileiro, não dá a proteção integral que o nascituro faz jus, tendo em vista que a Constituição Federal Brasileira, protege todos sem distinção, devendo haver a proteção integral de todo ser humano da forma mais abrangente possível.

\subsection{O nascituro e a Constituição Federal Brasileira de 1988}

A proteção integral do nascituro, encontra principal fulcro na Constituição Federal Brasileira, que tem como um de seus fundamentos, a dignidade da pessoa humana. A Lei Maior Brasileira traz uma série de direitos e garantias extensíveis ao nascituro, podendo-se destacar os principais em estudo: igualdade de todos perante a lei, inviolabilidade do direito à vida, liberdade, segurança, propriedade e entre outros dispostos no decorrer da Carta Magna.

Ingo Wolfgang Sarlet aduz que mesmo aquele que já perdeu a consciência da própria dignidade merece tê-la considerada e respeitada (2001, p. 50). Nessa linha de pensamento, o conjunto de direitos existenciais que compõem a dignidade, pertencem aos homens em igual proporção, sendo que o nascituro também é merecedor de tais proteções.

Além disso, o nascituro também deve ser protegido quanto ao direito à sua integridade física, assegurando para que não sofra traumas, deformações físicas ou outros danos, seguindo a ideia de que não deve haver qualquer forma de distinção ou discriminação. 
Nesse contexto, deve-se ampliar o cenário de proteção à todos os seres vivos, não importando em que grau de consciência aquele estiver, a fim de que seja integralmente todos os seus direitos tutelados. Partindo desse princípio, vejamos:

Não nos é lícito estabelecer limites aos nossos semelhantes por decorrência de sua condição atual ou devir. A integralidade do ser se manifesta no momento da vida, seja ela em que nível estiver - de consciência, de semi-consciência ou de absoluta falta de consciência. Se pensarmos de forma diversa, o ordenamento jurídico não asseguraria direitos aos incapazes, a contrário sensu, protege de forma integral os direitos dos tutelados e curatelados (REIS, 2010, p. 24).

Ainda, em consonância a essa ideia, a Constituição Federal prevê, também, a garantia do direito à vida de forma geral, inclusive uterina, cabendo ao Estado a proteção de tal premissa, tendo a obrigação de promover um desenvolvimento digno e sadio ao nascituro. Dessa forma, importante salientar que essas garantias não se enquadram apenas para aqueles que nasceram vivos, mas também, para todos aqueles que encontram-se concebidos e, consequentemente, com a expectativa de vida.

\subsection{O conflito aparente entre a Constituição Federal Brasileira e o Código Civil Brasileiro}

É de extrema importância, que os indivíduos exerçam seus direitos plenamente, mesmo que precisem de assistência ou representação. O Código Civil Brasileiro, em seu artigo $2^{\circ}$, restringe de forma clara, que os direitos do nascituro sejam percebidos desde sua concepção e isso, de uma forma ou de outra, está em contrassenso com a Constituição Federal Brasileira, que protege todos os indivíduos de forma igual e sem qualquer distinção.

Ora, vejamos, ao adotar a teoria da personalidade condicional trazida pelo art. $2^{\circ}$ do Código Civil, seria entrar em confronto com o princípio basilar do ordenamento jurídico brasileiro, trazido pela Constituição Federal, qual seja, o princípio da Dignidade Humana.

Seguindo essa linha de raciocínio, os direitos a personalidade são absolutos, intransmissíveis, indisponíveis, irrenunciáveis, ilimitados, impenhoráveis, imprescritíveis e inexpropriáveis (DINIZ, 2008). Por essa explanação, entende-se que a condição de nascituro, extrapola uma situação de expectativa de direito presente no Código Civil, uma vez que a Constituição Federal é muito mais abrangente, protegendo o nascituro (como qualquer ser humano) de forma concreta.

É pelo princípio da dignidade humana que a reparabilidade do dano extrapatrimonial encontra seu fundamento. Em conjunto com essa idéia, o estudioso do direito Francisco Amaral acrescenta que são sujeitos titulares dos direitos da personalidade:

Todos os seres humanos no ciclo vital de sua existência, isto é, desde a concepção, seja esta natural ou assistida (fertilização in vitro ou intratubária), como decorrência da garantia constitucional do direito à vida [...]. De modo mais específico, pode-se dizer que a proteção dos direitos da personalidade é de natureza constitucional, no que diz respeito aos princípios fundamentais que regem a matéria e que estão na Constituição, e é de matéria civil, penal, administrativa quando integrante da respectiva legislação ordinária (2003, p. 253-257).

Tal exposição corrobora com o entendimento de que desde a concepção o nascituro tem direitos, inclusive de dano extrapatrimonial que será visto adiante, deixando de lado a mera expectativa de direitos prevista no Código Civil e dando lugar à sua integral proteção prevista na Constituição Federal. 
Isso porque, os direitos da personalidade assumem papel determinante na vida das pessoas, afinal, a personalidade é o retrato de caráter das pessoas e assim:

Se é certo que os direitos patrimoniais materiais dependem do nascimento com vida para a plenitude de sua eficácia, notadamente quanto à transmissibilidade, os direitos da personalidade, incondicionais, como é o direito à vida, direito essencial e primeiro, não dependem daquela condição (CHINELATO, 2000, p. 304).

Portanto, verifica-se que o entendimento da personalidade condicional não é mais consoante com a atual ordem jurídica, posto que entra em choque com a realização plena da dignidade da pessoa humana.

Ademais, em que pese o objeto principal do presente trabalho ser o artigo $2^{\circ}$ do Texto Civilista, é notório, como já explanado, o fenômeno da constitucionalização do Direito Civil. Esse fenômeno nada mais é, do que a imposição de uma leitura dos institutos do Direito Civil conforme a Constituição Federal, sendo que a partir dessa premissa, a personalidade do nascituro deve ser interpretado à luz da dignidade da pessoa humana.

Analisando esse contexto, estabelece a autora Paula Roessing que:

Necessário observar que o espectro das valorações da "constitucionalização" tem de se situar dentro dos parâmetros constitucionais de ordenação, com respeito pelo papel de integração do sistema que, em última instância, a estes cabe (...). Assim está evidenciado em nossa Constituição em seu artigo $1^{\circ}$, que estabelece como fundamento da República Federativa do Brasil a dignidade da pessoa humana. No rol dos direitos fundamentais insere-se a inviolabilidade do direito à vida, à liberdade, à igualdade, à segurança e à propriedade, nos termos elencados (2001, p. 62).

Dessa forma, conforme aduz o estudioso de direito Juliano Paganini (2008), todos os interesses existenciais decorrentes da condição do nascituro como pessoa, dotada de personalidade jurídica, devem ser avaliados à luz da cláusula geral de proteção à dignidade da pessoa humana (artigo $1^{\circ}$, inciso III da $\mathrm{CF}$ ), uma vez que norma mais soberana em comparação às demais.

\section{A CONFUSÃO ENTRE DANO MORAL E DANO EXTRAPATRIMONIAL NA JURISPRUDÊNCIA E DOUTRINA BRASILEIRA}

Primeiramente, há que se falar em dois institutos muito presentes no direito e que, muitas vezes, acabam sendo confundidos entre si tanto doutrinariamente quanto em jurisprudências, conforme será visto mais adiante.

Isso acontece porque a linha que os distingue é muito tênue, sendo que sua interpretação conceitual não encontra-se em sua origem, mas sim, no dano efetivo e seus efeitos. A importância dessa distinção para o presente trabalho, é de que constantemente, de forma errônea, doutrinadores e estudiosos do direito fazem menção à dano moral, restringindo seu entendimento, quando na verdade trata-se de dano extrapatrimonial.

Além disso, a diferenciação entre o dano moral e o dano extrapatrimonial é extremamente importante para que seja aplicado de maneira correta, ainda mais quando se trata dos seus efeitos em relação ao nascituro, objeto alvo deste artigo. Para tanto, será visto a seguir conceitualmente cada um e a distinção entre eles, para mais tarde explicar sua aplicação em favor do nascituro. 


\subsection{Dano moral}

O Código Civil Brasileiro assegura um tratamento de suma importância nos casos de indenização ao dano moral, mais especificadamente nos artigos 186 e 927, onde obriga aquele que, por ato ilícito, causou dano a outrem ainda que exclusivamente de cunho moral, a reparar tal dano, através de ação competente para tal.

Os titulares da ação de reparação de dano moral, são aqueles ofendidos, cônjuges, companheiros, membros da família e etc., assim, caracteriza-se diretamente aquele que foi atingido, de frente, os reflexos danosos, por consequência de tal ato.

Conforme bem expõe o ilustre doutrinador Gustavo Tepedino (2007), que entende como dano moral, qualquer sofrimento ou incômodo humano não causado por perda pecuniária, mas sim, provocando dor, espanto, emoção, vergonha, injúria física ou moral, isto é, uma dolorosa sensação experimentada por alguém, em que atribui-se à palavra dor, seu mais largo significado. Já quanto a reparação do dano moral, tem-se que:

Não visa reparar no sentido literal da dor, pois esta não tem preço, mas aquilatar um valor compensatório para amenizar a dor moral. Para isso requer indenização autônoma, pelo critério de arbitramento, onde o Juiz fixará o quantum indenizatório, levando em conta as condições das partes nível social escolaridade o prejuízo que sofreu a vítima o grau de intensidade da culpa e tudo o mais que concorre para a fixação do dano (MICHELLAZZO, 2000, p. 22)

Assim, verifica-se que o dano moral insere-se em um plano mais subjetivo da pessoa que o sofreu, isto é, um aborrecimento extremamente significativo que sugere sua aplicação, compreendendo-se o dano moral como dor, sofrimento ou humilhação profunda.

\subsection{Dano Extrapatrimonial}

De acordo com o explanado anteriormente, o descumprimento de um dever jurídico provoca um abalo na ordem jurídica, significando uma lesão a um direito de alguém e desse fato decorrem perdas materiais ou extrapatrimoniais em face de determinado sujeito.

O conceito de dano extrapatrimonial, refere-se a lesão ou violação a um interesse juridicamente protegido, independentemente de qualquer repercussão na esfera íntima do lesado, isto é, para ocorrência do dano extrapatrimonial, basta a violação de um direito ou lesão de um interesse juridicamente protegido.

Nesse sentido, é possível colocar no pólo passivo como vítimas do dano em questão, doentes mentais, pessoas em estado vegetativo ou comatoso, crianças de tenra idade e, inclusive, o nascituro (CHAMONE, 2008), tendo em vista que tais seres citados não sentiram efetivamente o dano, uma vez que não possuem consciência para tal, porém, de alguma forma atingiu sua esfera, violando sua personalidade.

Seguindo a linha de que a personalidade constitui o mais importante estado de pessoa, expõe Sérgio Cavalieri:

Enquanto ser humano será detentora de um conjunto de bens integrantes de sua personalidade, mais precioso que o patrimônio. É a dignidade humana, que não é privilégio apenas dos ricos, cultos ou poderosos, que deve ser por todos respeitada (...) Os direitos da personalidade, entretanto, englobam outros aspectos da pessoa humana que não estão diretamente vinculados à sua dignidade (2012, p. 89). 
Deste modo, todas as vezes que ocorrer a violação de um direito ou interesse juridicamente protegido ficará o lesante obrigado a indenizar o lesado. Esta indenização possuirá apenas caráter punitivo, e terá como primordial função inibir ou coibir a prática ou a ocorrência de quaisquer ilícitos futuros.

\subsection{Distinção entre Dano Extrapatrimonial e Dano Moral}

Conforme acima exposto, dano moral e dano extrapatrimonial não compreendem o mesmo sentido. Focando-se na distinção entre os dois institutos, pode-se afirmar que danos morais seriam, por exemplo, aqueles decorrentes das ofensas à honra, ao decoro, à paz interior de cada qual, às crenças íntimas, aos sentimentos afetivos de qualquer espécie, enquanto dano extrapatrimonial, de maneira mais ampla, protege qualquer violação de um direito independentemente se atingiu, ou não, a esfera individual da pessoa.

Nesse mesmo sentido, o doutrinador Sérgio Severo, aduz que:

O fundamental é que a designação dano moral está bastante ligada á idéia de dor, mas, como já se pôde observar, a dor pode estar presente ou não. Portanto, a designação dano extrapatrimonial é mais ampla, é o gênero de que o dano moral é espécie (1996, p. 36).

Assim, pode-se perceber uma diferença pontual entre os denominados danos morais e os extrapatrimoniais. Isso porque, os primeiros repercutem na esfera íntima das pessoas, como por exemplo os sentimentos de dor, angústia, aflição, medo etc.. Já para o segundo, porém, apenas importa a ocorrência de um ato ou fato violador ou lesivo a um direito ou interesse juridicamente protegido, mesmo inexistindo qualquer reflexo nos direitos da personalidade ou na esfera íntima da vítima.

O doutrinador Gustavo Tepedino novamente menciona sobre o caráter que o dano moral possui, isto é, ligado intimamente à dor e humilhação, citando uma decisão do TJRJ em que houve confusão quanto ao conceito de dano moral e extrapatrimonial:

Tal imprecisão conceitual tem resultado em decisões extremamente controvertidas. Veja-se, a título de exemplo, a decisão do TJRJ (...), que declarou não haver dano moral na divulgação, não autoriza, de foto em que famosa atriz aparecia nua, sob o argumento de que, tratando-se de mulher bonita e atraente, sua exposição não poderia provocar vergonha ou humilhação (TJRJ, $2^{a}$ Gr. C.C., Emb. Infr. 250/99, Rel. Des. Wilson Marques, julg. 29.07.1999, publ. RDTJRJ 41/184-187). O STJ reformou o acórdão, entendendo que a atriz "é uma pessoa pública, mas nem por isso tem que querer que sua imagem seja publicada em lugar que não autorizou, e deve ter sentido raiva, dor, desilusão, por ter visto a sua foto em publicação que não foi de sua vontade" (STJ, $3^{\mathrm{a}} \mathrm{T}$., REsp. 270.730, Rel. p/Ac Min. Nancy Andrighi, julg. 19.12.2000, publ. Dj 07.05.2001) (2007, p. 340).

Percebe-se então que, ao atingir a esfera individual de alguém, causando-lhe dor, raiva ou outro sentimento íntimo, pode-se falar em aplicação de dano moral e, caso contrário, não restará caracterizado.

Ressalta-se que o dano moral possui um caráter compensatório, visando compensar a dor sofrida em consequência de determinado fato ilícito. Já a indenização relativa aos danos extrapatrimoniais, ao revés, possui caráter punitivo, intimidatório ou inibitório da prática de futuras agressões. A adoção de tal distinção permite ao magistrado ajustar melhor a indenização em cada caso concreto, permitindo a visualização dos aspectos punitivos e compensatório das 
verbas indenizatórias, evitando-se assim, que sejam fixadas insignificantes indenizações que não atingem os seus reais objetivos.

Portanto, diante da precisa distinção existente entre o dano moral e o dano extrapatrimonial, resta claro que alguns doutrinadores ao falar de dano moral, em verdade estão falando de dano extrapatrimonial. Assim como Ministros, Desembargadores e outras personalidades do direito, que acabam por citar erroneamente dano moral em favor do nascituro, quando na verdade trata-se de dano extrapatrimonial, pelos motivos explicados acima.

\section{APLICAÇÃO DO DANO EXTRAPATRIMONIAL EM FACE DO NASCITURO}

Esse tópico tem por objetivo demonstrar que é possível a aplicação do dano extrapatrimonial em face do nascituro, em eventual hipótese de tê-lo sofrido, apresentando doutrinas favoráveis e jurisprudências corroborando com a afirmativa.

Conforme o explicado no item anterior, as decisões encontradas manifestam-se em sua íntegra a explicação com a abrangência do termo "dano moral", porém, ressalta-se que o correto seria a utilização do termo: danos extrapatrimoniais.

O nascituro mesmo que não tenha discernimento da realidade, não tendo condições de valorar o ato que lhe causou o dano, pode vir a sofrê-lo, pois não se pode considerar que a ausência de compreensão a respeito dos fatos diminuiria sua personalidade jurídica, tendo ele direito a reparação, o que será visto no decorrer deste tópico.

\subsection{Justificativa legal e doutrinária da aplicação do Dano Extrapatrimonial em favor do nascituro}

Primordialmente, o dano extrapatrimonial apareceu muito antes do Código Civil Brasileiro, tendo como primeira aparição na Consolidação de Teixeira de Freitas, em seu artigo 800 que dizia: "A indenização será sempre a mais completa possível; no caso de dúvida, será a favor do ofendido" (FREITAS, 1896, p. 486).

Partindo desse princípio, verifica-se que desde o início procurou-se tutelar todas aquelas pessoas que pudessem sofrer algum dano, abrangendo da maior forma possível e da maneira mais completa.

Percebe-se que o conceito de dano extrapatrimonial encontra íntima ligação com a esfera da personalidade da vítima e com os valores fundamentais e essenciais da vida humana. E para Maria Helena Diniz (2008) os direitos da personalidade são tutelados em cláusula pétrea constitucional, não se dispersando com o tempo. Tal ensinamento corrobora com a afirmação de que a personalidade do nascituro é protegido pela Constituição Federal, tanto quanto uma pessoa já nascida, com capacidade plena. Dessa forma:

Não faz sentido deixar de atribuir a condição de dignidade ao nascituro porque ainda não nasceu. Ora, mesmo não tendo nascido, não perdeu a sua atribuição de um ser humano em fase de desenvolvimento. Nele se encontram presentes todos os elementos fundamentais e identificadores da pessoa humana e, por consequência, os direitos da personalidade suscetível de assegurar o direito à proteção jurídica através da tutela dos danos morais dentre outros. Aliás, é exatamente esse ser humano que anseia por nascer, totalmente indefeso, que merece a maior e a mais irrestrita proteção do ordenamento jurídico. A dignidade que se encontra presente neste ser indefeso é certamente maior em relação àqueles que possuem mecanismos de defesa própria, a exemplo dos animais irracionais. Nesse particular, a ordem jurídica é contraditória. $\mathrm{Na}$ medida em que oferece proteção aos enfermos e idosos, como a recente Lei 
sobre o Estatuto do Idoso, não assinala a especial tutela que deve merecer os nascituros (REIS, 2010, p.40-41).

Em relação a aplicação de dano extrapatrimonial em favor do nascituro, percebe-se que de acordo com os novos entendimentos jurisprudenciais, que serão vistos no item a seguir, além da crescente adoção da corrente concepcionista, ele é sim possível, vez que os direitos do nascituro devem ser preservados e aplicados no caso de sofrer algum dano, que este possa ser reparado na sua totalidade.

Conforme visto anteriormente, a Constituição Federal abrange conceitos importantes que favorecem a concessão de dano extrapatrimonial em favor do nascituro. $\mathrm{O}$ artigo $1^{\circ}$, inciso III da Carta Marga, estabelece a dignidade da pessoa humana como fundamento, não restringindo sua aplicação. Isso porque no artigo $3^{\circ}$, inciso IV e artigo $5^{\circ}$ "caput" da Lei Maior supracitada, a Constituição prevê o bem de todos, sem qualquer forma de distinção ou discriminação.

O doutrinador Paulo Lôbo, faz uma brilhante colocação quanto aos direitos da personalidade, explicando sobre sua inserção constitucional e sua relação com o dano moral (leiase dano extrapatrimonial):

A inserção constitucional dos direitos da personalidade e dos danos morais consagra a evolução pela qual ambos os institutos jurídicos têm passado. Os direitos da personalidade, por serem não patrimoniais, encontram excelente campo de aplicação nos danos morais, que têm a mesma natureza na patrimonial. Ambos têm por objeto bens integrantes da interioridade da pessoa, que não dependem da relação com os essenciais à realização da pessoa, ou seja, aquilo que é inato à pessoa e deve ser tutelado pelo direito. [...] A recepção dos danos morais foi o elo que faltava, pois constituem a sanção adequada ao dever absoluto de abstenção (2002, p. 348)

Dessa forma, embora o nascituro tenha expectativas de direitos patrimoniais condicionadas ao implemento da condição do nascimento com vida (teoria natalista), pode-se afirmar concretamente que ele é titular, desde a concepção, de direitos subjetivos personalíssimos de forma plena, tais como vida, integridade física, dignidade, imagem e honra (teoria concepcionista). A partir dessa explicação, vislumbra-se que, em possível caso de violação à integridade física do nascituro, há a configuração de dano extrapatrimonial.

Nesse sentido, Willian Arthur Pussi afirma que "a doutrina filiada à corrente concepcionista sustenta a colocação do nascituro no mesmo patamar de filho menor para fins de aferição de responsabilidade civil por danos, tais como morte ou violação de integridade física ou moral (2005, p. 387).

Assim, o nascituro, enquanto titular de direitos da personalidade, conforme acima demonstrado, pode igualmente sofrer danos extrapatrimoniais em decorrência de sua violação, ressaltando que não é necessária a comprovação do abalo subjetivo da vítima, bastando a demonstração a respeito da ocorrência do dano.

Percebe-se, portanto, que o caráter protecionista impera diante dos direitos atribuídos ao nascituro, pois ele tem o direito de nascer digna e normalmente. Ademais, a idéia central é de que a proteção a qualquer ser humano seja evidenciada da maneira mais ampla possível e assim, indenizando o nascituro no caso da ocorrência de algum dano para si.

\subsection{Entendimentos Jurisprudenciais}

Passando à análise das jurisprudências atuais no que se refere ao reconhecimento do dano extrapatrimonial em favor do nascituro, tem-se que o efeito da constitucionalização do 
direito civil tem gerado entendimentos favoráveis no Superior Tribunal de Justiça em relação à esse assunto.

Conexo a essa idéia, é o entendimento da referida Corte:

AGRAVO REGIMENTAL. AGRAVO EM RECURSO ESPECIAL. AÇÃO DE INDENIZAÇÃO. DANOS MATERIAIS E MORAIS. NASCITURO. PERDA DO PAI. 1.- Não há falar em omissão, contradição ou obscuridade no acórdão recorrido, que apreciou todas as questões que lhe foram submetidas de forma fundamentada, ainda que de modo contrário aos interesses da Recorrente. 2."O nascituro também tem direito aos danos morais pela morte do pai, mas a circunstância de não tê-lo conhecido em vida tem influência na fixação do quantum" (REsp 399.028/SP, Rel. Min. SÁLVIO DE FIGUEIREDO TEIXEIRA, DJ 15.4.2002). 3.- "A jurisprudência desta Corte é disposta no sentido de que o benefício previdenciário é diverso e independente da indenização por danos materiais ou morais, porquanto, ambos têm origens distintas. Este, pelo direito comum; aquele, assegurado pela Previdência; A indenização por ato ilícito é autônoma em relação a qualquer benefício previdenciário que a vítima receba"(AgRg no AgRg no REsp 1.292.983/AL, Rel. Min. HUMBERTO MARTINS, DJe 7.3.2012). 4.- "Em ação de indenização, procedente o pedido, é necessária a constituição de capital ou caução fidejussória para a garantia de pagamento da pensão, independentemente da situação financeira do demandado" (Súmula 313/STJ). 5.- "A apreciação do quantitativo em que autor e réu saíram vencidos na demanda, bem como a verificação da existência de sucumbência mínima ou recíproca, encontram inequívoco óbice na Súmula 7/STJ, por revolver matéria eminentemente fática" (AgRg nos EDcl no REsp 757.825/RS, Rel. Min. DENISE ARRUDA, DJe 2.4.2009). 6.- O recurso não trouxe nenhum argumento capaz de modificar a conclusão do julgado, a qual se mantém por seus próprios fundamentos. 7.- Agravo Regimental improvido. (STJ - AgRg no AgRg no AREsp: 150297 DF 2012/0041902-2, Relator: Ministro SIDNEI BENETI, Data de Julgamento: 19/02/2013, T3 - TERCEIRA TURMA, Data de Publicação: DJe 07/05/2013)

O dano sofrido pelo nascituro, vêm sendo reconhecido pelo STJ, tendo como principal tese o princípio constitucional da dignidade da pessoa humana. Assegurando a proteção integral daquele ainda não nascido, no ventre da mãe. Nesse sentido, é ainda o seguinte entendimento do Superior Tribunal em questão:

RESPONSABILIDADE CIVIL. ACIDENTE DO TRABALHO. MORTE. INDENIZAÇÃO POR DANO MORAL. FILHO NASCITURO. FIXAÇÃO DO QUANTUM INDENIZATÓRIO. DIES A QUO. CORREÇÃO MONETÁRIA. DATA DA FIXAÇÃO PELO JUIZ. JUROS DE MORA. DATA DO EVENTO DANOSO. PROCESSO CIVIL. JUNTADA DE DOCUMENTO NA FASE RECURSAL. POSSIBILIDADE, DESDE QUE NÃO CONFIGURDA A MÁ-FÉ DA PARTE E OPORTUNIZADO O CONTRADITÓRIO. ANULAÇÃO DO PROCESSO. INEXISTENCCIA DE DANO. DESNECESSIDADE. - Impossível admitir-se a redução do valor fixado a título de compensação por danos morais em relação ao nascituro, em comparação com outros filhos do de cujus, já nascidos na ocasião do evento morte, porquanto o fundamento da compensação é a existência de um sofrimento impossível de ser quantificado com precisão. Embora sejam muitos os fatores a considerar para a fixação da satisfação compensatória por danos morais, é principalmente com base na gravidade da lesão que o juiz fixa o valor da reparação. - É devida correção monetária sobre o valor da indenização por dano moral fixado a partir da data do arbitramento. 


\begin{abstract}
Precedentes. - Os juros moratórios, em se tratando de acidente de trabalho, estão sujeitos ao regime da responsabilidade extracontratual, aplicando-se, portanto, a Súmula $n^{\circ} 54$ da Corte, contabilizando-os a partir da data do evento danoso. Precedentes - É possível a apresentação de provas documentais na apelação, desde que não fique configurada a má-fé da parte e seja observado o contraditório. Precedentes. - A sistemática do processo civil é regida pelo princípio da instrumentalidade das formas, devendo ser reputados válidos os atos que cumpram a sua finalidade essencial, sem que acarretem prejuízos aos litigantes. Recurso especial dos autores parcialmente conhecido e, nesta parte, provido. Recurso especial da ré não conhecido. (STJ - REsp: 931556 RS 2007/0048300-6, Relator: Ministra NANCY ANDRIGHI, Data de Julgamento: 17/06/2008, T3 - TERCEIRA TURMA, Data de Publicação: DJe 05/08/2008).
\end{abstract}

Conforme jurisprudências acima demonstradas, a frustração da convivência familiar, é hipótese interessante de reparação de danos ao nascituro, sendo que é inegável que ao perder o pai, mesmo o nascituro sofre, ficando prematuramente privado da companhia do genitor e de sua orientação. Portanto, eventual violação à vida e à integridade física do nascituro configuram dano extrapatrimonial, tal como se pessoa nascida fosse.

Muito embora o Superior Tribunal de Justiça já tenha decidido de forma favorável ao nascituro, observa-se que não há decisões acerca do caso específico aqui tratado no âmbito do Supremo Tribunal Federal. Contudo, é possível constatar que o STF tem adotado a teoria natalista ao julgar a Ação Direta de Inconstitucionalidade $\mathrm{n}^{\mathbf{o}} 3510$, votando pela total improcedência da ação, ementa a seguir colacionada:

CONSTITUCIONAL. AÇÃO DIRETA DE INCONSTITUCIONALIDADE. LEI DE BIOSSEGURANÇA. IMPUGNAÇÃO EM BLOCO DO ART. $5^{\circ}$ DA LEI N 11.105, DE 24 DE MARÇO DE 2005 (LEI DE BIOSSEGURANÇA). PESQUISAS COM CÉLULAS-TRONCO EMBRIONÁRIAS. INEXISTÊNCIA DE VIOLAÇÃO DO DIREITO À VIDA. CONSITUCIONALIDADE DO USO DE CÉLULAS-TRONCO EMBRIONÁRIAS EM PESQUISAS CIENTÍFICAS PARA FINS TERAPÊUTICOS. DESCARACTERIZAÇÃO DO ABORTO. NORMAS CONSTITUCIONAIS CONFORMADORAS DO DIREITO FUNDAMENTAL A UMA VIDA DIGNA, QUE PASSA PELO DIREITO À SAÚDE E AO PLANEJAMENTO FAMILIAR. DESCABIMENTO DE UTILIZAÇÃO DA TÉCNICA DE INTERPRETAÇÃO CONFORME PARA ADITAR À LEI DE BIOSSEGURANÇA CONTROLES DESNECESSÁRIOS QUE IMPLICAM RESTRIÇÕES ÀS PESQUISAS E TERAPIAS POR ELA VISADAS. IMPROCEDÊNCIA TOTAL DA AÇÃO. [...] A PROTEÇÃO CONSTITUCIONAL DO DIREITO Ä VIDA E OS DIREITOS INFRACONSTITUCIONAIS DO EMBRIÃO PRÉ-IMPLANTO. O Magno Texto Federal não dispõe sobre o início da vida humana ou o preciso instante em que ela começa. Não faz de todo e qualquer estádio da vida humana um autonomizado bem jurídico, mas da vida que já é própria de uma concreta pessoa, porque nativiva (teoria "natalista", em contraposição às teorias "concepcionista" ou da "personalidade condicional"). E quando se reporta a "direitos da pessoa humana" e até dos "direitos e garantias individuais" como cláusula pétrea está falando de direitos e garantias d indivíduo-pessoa, que se faz destinatário dos direitos fundamentais "à vida, à liberdade, à igualdade, à segurança e à propriedade", entre outros direitos e garantias igualmente distinguidos com o timbre da fundamentalidade (como direito à saúde e ao planejamento familiar). Mutismo constitucional hermeneuticamente significante de transpasse de poder normativo para a legislação ordinária. A potencialidade de algo para se tornar pessoa humana já é meritória o bastante para acobertá- 
la, infraconstitucionalmente, contra tentativas levianas ou frívolas de obstar sua natural continuidade fisiológica. Mas as três realidades não se confundem: o embrião é o embrião, o feto é o feto e a pessoa humana é a pessoa humana. Donde não existir pessoa humana embrionária, mas embrião de pessoa humana. O embrião referido na Lei de Biossegurança ("in vitro" apenas) não é uma vida a caminho de outra vida virginalmente nova, porquanto lhe faltam possibilidades de ganhar as primeiras terminações nervosas, sem as quais o ser humano não tem factibilidade como projeto de vida autônoma e irrepetível. $O$ Direito infraconstitucional protege por modo variado cada etapa do desenvolvimento biológico do ser humano. Os momentos da vida humana anteriores ao nascimento devem ser objeto de proteção pelo direito comum. $\underline{\mathrm{O}}$ embrião pré-implanto é um bem a ser protegido, mas não uma pessoa no sentido biográfico a que se refere a Constituição. [...] Ação direta de inconstitucionalidade julgada totalmente improcedente.

Utilizando o entendimento favorável do STJ anteriormente colacionado como fundamento para sua decisão, o Tribunal de Justiça do Paraná - TJPR também decidiu positivamente à aplicação de dano extrapatrimonial ao nascituro, interpretando como legítima a configuração do nascituro no polo ativo da demanda. Senão vejamos:

APELAÇÃO CÍVEL(O1 e O2) E AGRAVO RETIDO. AGRAVO RETIDO. INDENIZAÇÃO POR DANOS MORAIS. NASCITURO. ALEGAÇÃO DE ILEGITIMIDADE PASSIVA. INOCORRÊNCIA. DESPROVIMENTO. APELAÇÃO CÍVEL. AÇÃO INDENIZATÓRIA POR DANOS MATERIAIS E MORAIS. CONTRATO DE PRESTAÇÃO DE SERVIÇOS. COLETA DE CÉLULAS TRONCO EMBRIONÁRIAS E ARMAZENAMENTO SOB O REGIME DE CRIOPRESERVAÇÃO. MOMENTO PARA COLETA DO MATERIAL. HORA DO PARTO. INOCORRÊNCIA DA COLETA. NÃO CUMPRIMENTO DO ACORDO PELA CONTRATADA. DANO MORAL DEVIDAMENTE CARACTERIZADO. MONTANTE ARBITRADO EM VALOR QUE NÃO SE CONSTITUI EM FATOR SUFICIENTE PARA FRENTE AO DANO MORAL PERPETRADO. MAJORAÇÃO QUE SE DETERMINA. DANO MORAL. NOVO ARBITRAMENTO DE VALOR QUE SE IMPÕE. DEVOLUÇÃO EM DOBRO. IMPOSSIBILIDADE. AUSENCIA DE PEDIDO EXPRESSO. DEVOLUÇÃO NA FORMA SIMPLES. AGRAVO RETIDO DESPROVIDO. APELO I, PROVIDO. APELO II, PARCIALMENTE PROVIDO. (TJPR - $11^{\text {a }}$ C. Cível - AC - 621909-0 - Curitiba - Rel.: Luiz Antônio Barry - Unânime - - J. 26.05.2010)

Outro exemplo atual de concessão de dano extrapatrimonial em favor do nascituro e, dessa vez, resultou em alcance nacional, foi o caso da popular cantora Wanessa Camargo e sua família (marido e nascituro) contra o comediante "Rafinha Bastos", pleiteando a fixação de danos extrapatrimoniais, em razão de ofensa feita pelo comediante em face da cantora e de seu filho que havia por nascer. Configuraram no polo ativo da demanda, a cantora, seu marido e o nascituro da geração de ambos. Em sentença, houve a condenação do comediante ao pagamento de um valor a título de dano extrapatrimonial, tanto para os genitores, quanto para o nascituro figurado no polo ativo da demanda. ${ }^{1}$

No caso acima comentado, Luiz Beethoven Giffoni Ferreira - juiz de direito que julgou o caso, bem explanou em sua sentença que a figura da pessoa surgida com a concepção

\footnotetext{
1 Justiça condena Rafinha Bastos por danos morais. Migalhas. Rio de Janeiro, 18 jan. 2012. Disponível em: $<$ http://www.migalhas.com.br/Quentes/17,Ml148238,31047-

Caso+Wanessa+Camargo+Justica+Condena+Rafinha+Bastos+por+danos+morais>. Acesso em: 17 ago. 2015.
} 
embrionária antecede a personalidade civil e sendo assim, a esfera moral do nascituro poderá evidentemente sofrer vulneração, pelo simples fato de que já é pessoa para os fins preconizados na Lei (2012).

Conclui-se que nesses casos demonstrados, atingiu-se a honra objetiva do nascituro, fazendo jus ao dano extrapatrimonial. Quanto à esse instituto aduz Sérgio Cavalieri Filho:

A honra subjetiva, que se caracteriza pela dignidade, decoro e autoestima, é exclusiva do ser humano, mas a honra objetiva, refletida na reputação, no bom nome e na imagem perante a sociedade, é comum à pessoa natural e à jurídica. [...] Objetivamente, é a opinião dos outros sobre o nosso mérito; subjetivamente, é o nosso receio diante dessa opinião (2012, p. 109).

Assim, verifica-se que o reconhecimento da possibilidade de concessão do dano extrapatrimonial em favor do nascituro, vem se fazendo presente nos entendimentos dos tribunais mencionados, reforçando, assim, a tese de que basta que seja atingida a honra objetiva daquele que há de nascer, para que se faça jus à indenização em caso de eventual violação de seus direitos.

\subsection{Breve explanação sobre o Projeto do Estatuto do Nascituro}

Há que se falar ainda, no projeto do Estatuto do Nascituro (em anexo), que trata dos seus direitos fundamentais. Este documento pretende tornar integral a proteção ao feto, realçando-se o direito à vida, saúde, honra, integridade física, alimentação, convivência familiar e etc. Favorável a esse estudo, tem-se que:

Admitir ser o embrião uma potencialidade de pessoa é aceitar que, entre o que é hoje e o homem e que ele será, no futuro, há uma distância a ser percorrida. $\mathrm{O}$ ser concebido deve ser visto, isto sim, como uma pessoa humana in fieri, ou pessoa humana com um potencial. Assim ele próprio sinalizará o reconhecimento de sua dignidade e a proteção de sua pessoa. $\mathrm{O}$ direito do embrião deve harmonizar-se com outros direitos, talvez menos fundamentais que a dignidade. Além do mais, é preciso ressaltar a impropriedade do postulado, para pensar que o caráter contínuo do desenvolvimento do fenômeno vital torna improvável o corte da vida, desde a concepção à morte, em categorias submetidas, cada uma delas, a um direito diferente. Assim, dotar um embrião de um estatuto, como se propõe, será sempre uma louvável ideia (BERTI, 2008, p. 90-91).

Outra defensora de tal Estatuto é Zélia Maria Cardoso Montal, que aduz: "O nascituro é sujeito de direito, pelos simples fato de estar na condição de ser humano, devido ao princípio da igualdade material ou substancial" (MONTAL, 2009).

Esse Estatuto busca, assim, maior qualidade e proteção em toda a gestação daquele que um dia, há de nascer. Fazendo com que o nascituro tenha seus direitos efetivados em caso de violação dos mesmos.

\section{CONSIDERAÇÕES FINAIS}

Diante do exposto, percebe-se que há grande discussão sobre os direitos do nascituro e o início da sua personalidade. Quanto ao objeto desse artigo, discute-se qual seria a teoria civilista a ser adotada para possível concessão ou não do dano extrapatrimonial em favor do mesmo. 
Verifica-se que, conforme interpretação sistemática do artigo $2^{\circ}$, do Código Civil Brasileiro, o nascituro possui mera expectativa de direitos, vez que adotada a teoria da personalidade condicional, o qual afirma que a pessoa natural começa sua existência com o nascimento com vida, porém estando garantidos os seus direitos desde a concepção.

Ocorre que, conforme já explanado, há uma crescente aplicação da teoria concepcionista, garantindo certa equiparação entre os já nascidos e aqueles viventes ainda no ventre materno. Isso porque, o Direito deve ser entendido como uma criação humana que visa harmonizar a convivência em sociedade, protegendo e assegurando à todos, sem distinção, os seus valores e sua dignidade. Nesse sentido cumpre dizer que, nos termos do artigo $5^{\circ}$, inciso XXXV da $\mathrm{CF}$, é assegurada a proteção jurisdicional de qualquer ameaça ou efetiva lesão a direitos.

Portanto, se até mesmo no Código Civil Brasileiro, ao resguardar os direitos do nascituro, adotando a teoria da personalidade condicional, acaba por admitir a existência de direitos fundamentais à ele, é inegável admitir-se que é devida a reparação, pela via judicial, de danos a ele causados em decorrência de eventual violação desses direitos, como no caso dos danos extrapatrimoniais.

No que tange aos referidos danos, eles podem ser concedidos ao nascituro e ser reconhecidos de pleno direito ao mesmo, uma vez que os valores primordiais são indispensáveis ao seu saudável desenvolvimento. Nesse sentido, a discussão acerca do início da vida não é unânime, porém, ressalta-se que a crescente corrente concepcionista tende a afirmar categoricamente que o nascituro é titular de direitos subjetivos, isto é, patrimoniais e inclusive os extrapatrimoniais, corroborando que há personalidade jurídica desde a concepção.

Diante da fragilidade que caracteriza a figura do nascituro, é necessário a concessão de ampla tutela jurídica aos seus direitos, o que já ocorre em alguns outros ramos do ordenamento jurídico brasileiro, já citados no desenvolvimento do presente trabalho e, em específico, quanto a possibilidade de concessão de dano extrapatrimonial em seu favor. A nova perspectiva civilista, imposta pelo princípio constitucional da dignidade da pessoa humana, vem sendo ratificada pela jurisprudência atual, caminhando no sentido de cada vez mais buscar reconhecer os direitos do nascituro, já que diversos entendimentos são favoráveis nesse sentido.

Imperioso esclarecer, que a cláusula da dignidade da pessoa humana, fundamento da Lei Maior, passa a figurar como parâmetro de delimitação daquilo que é passível de tutela no ordenamento jurídico brasileiro. Esse é o chamado fenômeno da constitucionalização do Direito Civil, o qual busca interpretar suas normas à luz da Constituição Federal.

De igual forma, todos os interesses existenciais decorrentes da condição do nascituro como pessoa, dotado de personalidade jurídica devem ser analisados à luz da cláusula geral de proteção à dignidade da pessoa humana.

Nesse contexto, ressalta-se que deve haver a proteção do ser humano em sua integralidade, em qualquer momento da vida, seja ela em nível de consciência, semi-consciência ou de absoluta falta de consciência, sendo que a limitação aos direitos da personalidade é algo inadmissível.

Pode-se afirmar ainda, que os direitos da personalidade, seguindo a perspectiva enraizada na Constituição Federal Brasileira de 1988, traduzem fielmente aqueles direitos do nascituro protegidos desde a concepção (previsto no artigo $2^{\circ}$, do Código Civil de 2002), fazendo com que todos os interesses e direitos do nascituro se efetivem, antes mesmo do seu nascimento com vida, visando maior proteção à sua dignidade e observância efetiva dos seus direitos da personalidade.

Assim, impõe-se que cabe ao nascituro o direito de ser indenizado de eventuais danos extrapatrimoniais que este possa vir a sofrer, no caso de violação a quaisquer dos seus direitos da personalidade. Tal tese apresenta-se como expressão do princípio da dignidade da pessoa 
humana, o qual deve ser estendido ao já concebido e ainda não nascido, uma vez que a falta de consciência, conforme anteriormente falado, não pode ser excludente dessa possibilidade.

Por fim, consagra-se que a vida intrauterina deve ser abarcada do mais absoluto respeito pela vida e integridade física do nascituro, sendo assim, são suscetíveis de indenização por danos extrapatrimoniais por ele sofridos em seu nome, seguindo a esteira de entendimento do Superior Tribunal de Justiça e Tribunal de Justiça do Paraná. De outro vértice, a negativa de indenização prestigiaria o ato ilícito que impediu a conquista da personalidade, indo contra aos princípios basilares do ordenamento jurídico brasileiro.

Outrossim, nesta linha conclui-se que, ainda que o texto normativo não reconheça expressamente o nascituro como agente capaz, garante cada vez mais direitos para conhece-lo como pessoa, se tornando cada vez mais efetiva a possibilidade de concessão de dano extrapatrimonial em seu favor, contudo, tal tema está longe de ser pacífico, razão pela qual se torna importante expor sobre os direitos que o nascituro possui, a fim de que ele seja protegido de toda forma em qualquer situação.

\section{REFERÊNCIAS}

ALMEIDA, Silmara J. A. Chinelato e. Tutela civil do nascituro. São Paulo: Saraiva, 2000.

AMARAL, Francisco. Direito Civil. 5 ed. Rio de Janeiro: Renovar, 2003.

BERTI, Silva Mendes. Os direitos do nascituro. Belo Horizonte: PUC Minas, 2008.

BEVILAQUA, Clóvis. Código Civil dos Estados Unidos do Brasil comentado. 2 ed. Rio de Janeiro: Azevedo, 1959.

BRASIL. Projeto de Lei $\mathrm{n}^{\circ}$ 478/2007. Câmara dos Deputados. Disponível em: <http://www.camara.gov.br/proposicoesWeb/prop_mostrarintegra?codteor=443584>. Acesso em: 22 jul. 2015. Referente ao anexo do Projeto do Estatuto do Nascituro.

CAVALIERI, Sérgio Filho. Programa de responsabilidade civil. 10 ed. São Paulo: Atlas, 2012.

CHAMONE, Marcelo Azevedo. O dano na responsabilidade civil. JUS NAVIGANDI, 2008. Disponível em <http://jus.com.br/artigos/11365/o-dano-na-responsabilidade-civil>. Acesso em: 22 mar. 2015.

COELHO, Fabio Ulhoa. Curso de direito civil. São Paulo: Saraiva, 2003.

DINIZ, Maria Helena. Curso de direito civil brasileiro. 25 ed. São Paulo: Saraiva, $200 \varepsilon$

ESPOLADOR, Rita de Cássia. Manipulação genética humana. UFPR, 2010. Disponível em:<http://dspace.c3sl.ufpr.br:8080/dspace/bitstream/handle/1884/24335/Rita\%20Tarifa.pdf?seq uence $=1 \&$ is Allowed=y $>$. Acesso em: 28 jul. 2015.

FERREIRA, Luiz. Caso Wanessa Camargo. MIGALHAS, 2012. Disponível em: <http://www.migalhas.com.br/Quentes/17,MI148238,31047Caso+Wanessa+Camargo+Justica+c ondena+Rafinha+Bastos+por+danos+morais>. Acesso em: 27 jul. 2015. 
FREITAS, Teixeira. Consolidação das Leis Civis. 3 ed. Rio de Janeiro: Garnier, 1896.

LÔBO, Paulo Luiz Netto. Danos morais e direitos da personalidade. Rio de Janeiro: Forense, 2002.

MADEIRA, Hélcio Maciel França. O nascituro no direito romano. 1 ed. São Paulo: Companhia Editora Nacional, 2005.

MEIRELLES, Jussara Maria Leal de. A vida humana embrionária e sua proteção jurídica. Rio de Janeiro: Renovar, 2000.

MICHELLAZZO, Busa Mackenzie. Do dano moral. 4 ed. São Paulo: Lawbook, 2000.

MIRANDA, Pontes de. Tratado de direito privado. Parte especial, Tomo IX. 4 ed. São Paulo: Revista dos Tribunais, 1974.

MONTAL, Zélia Maria Cardoso. Biodireito Constitucional: Questões atuais. Rio de Janeiro: Elsevier, 2009.

PAGANINI, Juliano Marcondes. Nascituro: da personalidade jurídica à reparação de danos. UFPR, 2008. Disponível em: <http://dspace.c3sl.ufpr.br:8080/dspace/bitstream/handle/1884/30959/M\%201038.pdf?sequence= 1\&isAllowed=y>. Acesso em: 10 jun. 2015.

PEREIRA, Caio Mário. Instituições de Direito Civil. 21 ed. Rio de Janeiro: Forense, 2014.

PUSSI, Willian Arthur. Personalidade jurídica do nascituro. Curitiba: Juruá, 2005.

REIS, Clayton. A dignidade do nascituro. 3 ed. Curitiba: Juruá, 2010.

ROESSING, Paula. Pessoa humana e personalidade jurídica: da dimensão filosófica à proteção jurídica. $\quad$ UFPR, 2001. Disponível em: <http://dspace.c3sl.ufpr.br:8080/dspace/bitstream/handle/1884/38004/M077.pdf?sequence=1\&is Allowed=y>. Acesso em: 29 jul. 2015.

SARLET, Ingo Wolfgang. Dignidade da pessoa humana e direitos fundamentais na Constituição Federal de 1988. Porto Alegre: Livraria do Advogado, 2001.

SEMIÃO, Sérgio Abdalla. Os direitos do nascituro: aspectos cíveis, criminais e do Biodireito. 2 ed. Belo Horizonte: Del Rey, 2000.

SEVERO, Silvio. Os danos extrapatrimoniais. São Paulo: Saraiva, 1996.

TEPEDINO, Gustavo. Código Civil Interpretado. 2 ed. Rio de Janeiro: Renovar, 2007. 